\title{
Research on the Construction and Application of Online and Offline Blending Teaching and Learning Model
}

\author{
Guo Xingxiang ${ }^{1} *$ Zhang Yuye ${ }^{2}$ Li Weiling ${ }^{3}$ Zhang Suqin ${ }^{4} \mathrm{Li} \mathrm{Li}^{5} \mathrm{Li} \mathrm{Kun}^{6}$
}

\author{
${ }^{123456}$ Naval Aviation University, Qingdao Branch, Qingdao, Shandong, 266041, China \\ *Corresponding author. Email: sddygxx@126.com
}

\begin{abstract}
Online and offline teaching have their own advantages and disadvantages. The author combines many years of teaching experience and makes full use of the advantages of online and offline teaching to carry out teaching mode reform and application in the course of management modeling and solution, which greatly improves learning efficiency and teaching effect.
\end{abstract}

Keywords: Blending teaching and learning, online teaching, offline teaching

\section{INTRODUCTION}

The rapid development of Internet technology has brought about the innovation of education and teaching methods and opportunities for the development of online courses. It has become a new subject of classroom teaching reform in the network era to integrate the traditional offline and online courses effectively, change the traditional "teacher-centered" offline teaching mode, use online resources to assist teaching, and improve the integration and application ability of students' theoretical knowledge Taking the course "Management Modeling and Solution" as an example, this paper explores the online and offline blending teaching mode, analyzes and summarizes the characteristics and effects in the application process, so as to provide a reference for the reform of university classroom teaching model.

\section{ONLINE AND OFFLINE BLENDING TEACHING}

With the deep application of information technology in teaching, blending teaching has been widely concerned at home and abroad. In foreign educational technology research, "Blended learning" is generally translated as "Mixed teaching". Combined with the expression of foreign scholars on this kind of research, it is generally based on the optimization of teaching process and the improvement of teaching efficiency to achieve the required teaching objectives.[1]

There are three typical expressions of Blending Teaching by domestic scholars: one is an organic integration of offline and online teaching method in order to reduce learning cost and improve learning efficiency. Second, in order to achieve the teaching goal, the teaching elements should be reasonably selected and combined, which can also be called "integrated teaching". Third, combining the advantages of online and offline teaching can give full play to the leading position of teachers and the subjective initiative of students.[2,3]

The author believes that online and offline blending teaching is to design the teaching process reasonably, give full play to the advantages of online teaching flexibility, convenience and good interaction of offline teaching, improve the teaching efficiency and better achieve the teaching objectives.[4]

After sufficient investigation and questionnaire, the online and offline teaching are compared in terms of teaching completion rate, student scale, learning time control, learning situation, individualized teaching, teaching interaction, etc., as shown in Figure 1.

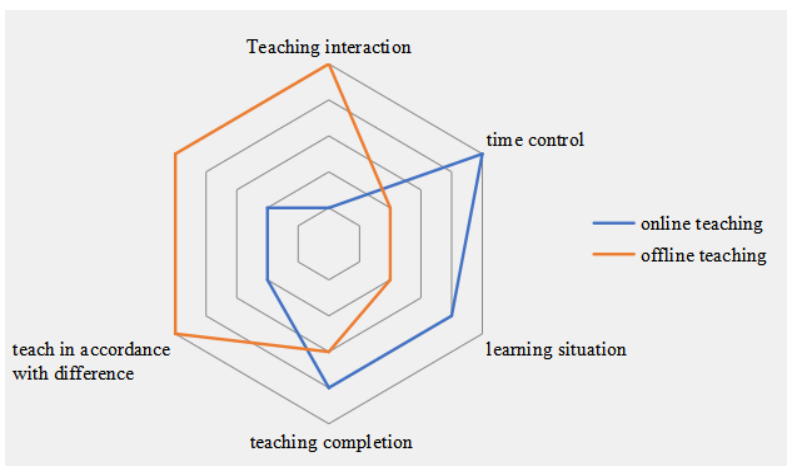

Figure 1 Comparison of online and offline teaching

Through comparison, it is found that the advantages of online teaching lie in the large scale of students, digital learning completion rate and flexible learning time control; the advantages of offline teaching lie in the good teaching interaction in small class teaching, and the real-time guidance according to the situation, teaching according to the aptitude and real-time control over the learning state of students.[5] 


\section{DESIGN OF ONLINE AND OFFLINE BLENDING TEACHING MODE}

The course of management modeling and solution belongs to the professional background course of management major in Colleges and universities, with a total of 40 class hours.It is a compulsory course for management majors to pay equal attention to both theory and practice.Combined with the characteristics of the course, the online and offline blending teaching mode is introduced for the reform and practice of the course.

The design of online and offline blending teaching mode is divided into four parts.The first part is the analysis of learning situation, which is mainly to understand the teaching object, define the teaching content and evaluate the teaching environment; the second part is the curriculum design, which mainly includes the recording of online video, preparing slides and materials, and making the teaching task list; the third part is the teaching implementation, carrying out the online and offline mixed teaching, forming the teaching mode of "teacher leading, student main body"; the fourth part, Part for teaching evaluation, combined with the actual learning situation of students to give the course assessment results.As shown in Figure 2.

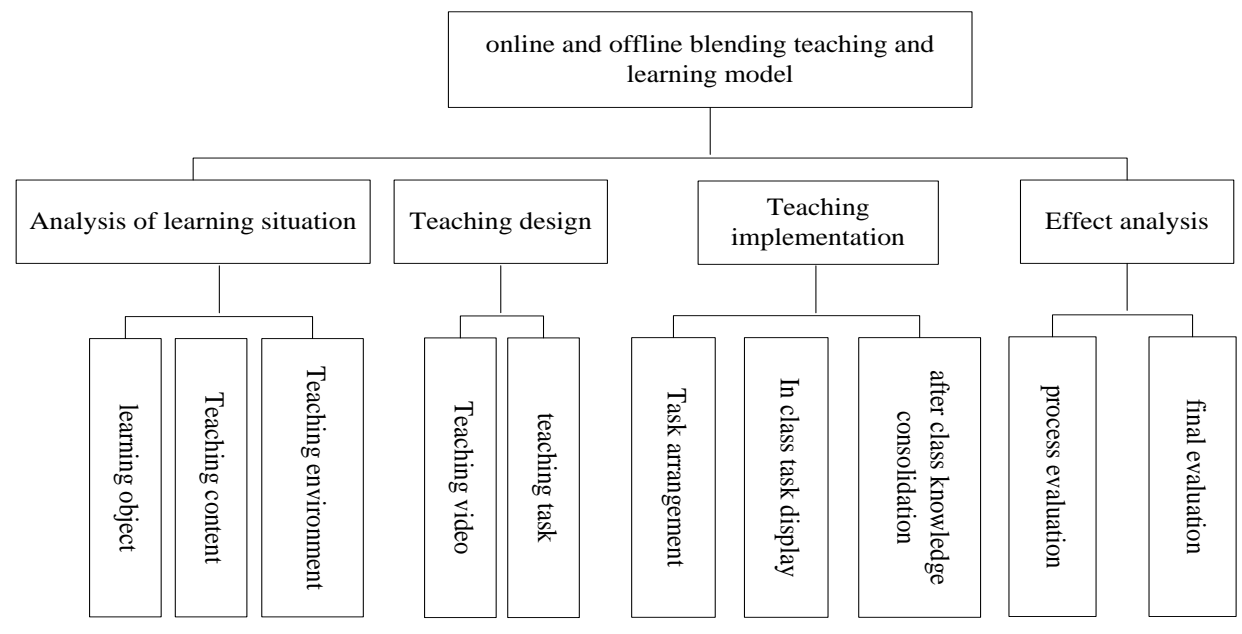

Figure 2 overall design of online and offline blending teaching

\section{IMPLEMENTATION OF ONLINE AND OFFLINE BLENDING TEACHING MODE}

\subsection{Analysis of learning situation}

The learning object of management modeling and solution course is the third year students of management major. From the questionnaire survey, it is found that the students have a certain mathematical basis for modeling and a certain foundation for computer software application.At the same time, the number of students is more suitable for offline flipped classroom. The main content of this course is the model establishment and computer solution of management problems.The construction of smart classroom on campus and the application of MOOC platform ensure that students can carry out online teaching by means of computers, mobile phones, pad and other ways.

\subsection{Teaching design}

In the process of teaching design, two aspects should be considered: using online education platform scientifically to improve teaching efficiency; paying attention to the generation of students\&apos; ability and optimizing teaching process; paying attention to students\&apos; main position and orderly flipping interaction.

According to the syllabus and course characteristics of management modeling and solution, the knowledge points of each chapter are divided according to the model, and 6 teaching units and 12 teaching and learning sub tasks are divided for course design. See Table 1 for the breakdown of course tasks. 
Table 1 Task decomposition of management modeling and solution

\begin{tabular}{|c|c|c|c|c|}
\hline Teaching unit & Teaching sub-task & Online teaching & Offline Teaching & teaching method \\
\hline \multirow{2}{*}{$\begin{array}{l}\text { Establishment and } \\
\text { solution of linear } \\
\text { programming model }\end{array}$} & Resource allocation & \multirow{2}{*}{$\begin{array}{c}\text { Microlecture } \\
\text { Virtual simulation }\end{array}$} & \multirow{2}{*}{$\begin{array}{l}\text { Group mutual } \\
\text { evaluation }\end{array}$} & \multirow[b]{2}{*}{ Flipped Classroom } \\
\hline & $\begin{array}{l}\text { transportation } \\
\text { problem }\end{array}$ & & & \\
\hline \multirow{2}{*}{$\begin{array}{c}\text { Establishment and } \\
\text { solution of integer } \\
\text { linear programming } \\
\text { model }\end{array}$} & $\begin{array}{l}\text { Distribution } \\
\text { problems }\end{array}$ & \multirow{2}{*}{$\begin{array}{c}\text { Microlecture } \\
\text { Virtual simulation }\end{array}$} & \multirow{2}{*}{$\begin{array}{l}\text { Group } \\
\text { presentation }\end{array}$} & \multirow[t]{2}{*}{ Flipped Classroom } \\
\hline & assignment problem & & & \\
\hline \multirow[b]{2}{*}{$\begin{array}{l}\text { Establishment and } \\
\text { solution of dynamic } \\
\text { programming model }\end{array}$} & Liquidity issues & \multirow[b]{2}{*}{$\begin{array}{c}\text { Microlecture } \\
\text { Virtual simulation }\end{array}$} & \multirow[b]{2}{*}{ panel discussion } & \multirow[b]{2}{*}{ Flipped Classroom } \\
\hline & $\begin{array}{l}\text { Production and sales } \\
\text { problems }\end{array}$ & & & \\
\hline \multirow{2}{*}{$\begin{array}{l}\text { Establishment and } \\
\text { solution of objective } \\
\text { decision model }\end{array}$} & $\begin{array}{l}\text { Single objective } \\
\text { problem }\end{array}$ & \multirow{2}{*}{$\begin{array}{c}\text { Microlecture } \\
\text { Virtual simulation }\end{array}$} & \multirow{2}{*}{$\begin{array}{l}\text { Classroom } \\
\text { presentation }\end{array}$} & \multirow{2}{*}{ Flipped Classroom } \\
\hline & $\begin{array}{l}\text { Multiobjective } \\
\text { problem }\end{array}$ & & & \\
\hline \multirow{2}{*}{$\begin{array}{l}\text { Establishment and } \\
\text { solution of network } \\
\text { planning model }\end{array}$} & $\begin{array}{l}\text { Maximum and } \\
\text { minimum flow } \\
\text { problems }\end{array}$ & \multirow{2}{*}{$\begin{array}{c}\text { Microlecture } \\
\text { Virtual simulation }\end{array}$} & \multirow{2}{*}{$\begin{array}{l}\text { Group } \\
\text { presentation }\end{array}$} & \multirow[t]{2}{*}{ Flipped Classroom } \\
\hline & $\begin{array}{c}\text { Shortest path } \\
\text { problem }\end{array}$ & & & \\
\hline \multirow[b]{2}{*}{$\begin{array}{l}\text { Establishment and } \\
\text { solution of nonlinear } \\
\text { programming model }\end{array}$} & Portfolio issues & \multirow[b]{2}{*}{$\begin{array}{c}\text { Microlecture } \\
\text { Virtual simulation }\end{array}$} & \multirow[b]{2}{*}{$\begin{array}{l}\text { Group mutual } \\
\text { evaluation }\end{array}$} & \multirow[b]{2}{*}{ Flipped Classroom } \\
\hline & Best match question & & & \\
\hline
\end{tabular}

\subsection{Teaching implementation}

\subsubsection{Task arrangement}

Before class 72 hours, teachers upload video resources such as teaching tasks and micro lessons to MOOC platform; students complete online learning, complete online exercises, and conduct online communication with team members; send doubts in the learning process to teachers. Teachers collect online data, master doubts data, and prepare lessons according to local conditions.

\section{3.2. In class task display}

Explain the doubts of each group, break down the key points and overcome the difficulties.After that, the teaching subtasks are arranged, completed in groups, displayed in groups, discussed in class, and the key and difficult points are consolidated.For example, in the multi-objective planning, there are differences in the results of group experiments. Through the display of each group member, we can quickly find out their own mistakes and solve them.It not only solves the problem, but also avoids the possible mistakes.Finally, the teacher makes a summary of the comments.

\subsubsection{After class knowledge consolidation}

Management modeling and solution is a practical course with high theoretical requirements, and corresponding consolidation assignments are arranged according to the learning tasks in the after class stage.Students submit assignments on the MOOC platform and complete the experiment.The instructor scores online. 
Table 2 Course implementation process

\begin{tabular}{|c|c|l|}
\hline Stage & \multicolumn{1}{|c|}{ Teacher } & \multicolumn{1}{c|}{ Student } \\
\hline before class & Release learning tasks and guide students to learn independently & Online learning, online communication \\
\hline In class & Review online learning and guide comments & Group into tasks, exchange and display \\
\hline after class & Platform exchange, questionnaire information analysis & $\begin{array}{l}\text { Finish homework, consolidate and } \\
\text { improve }\end{array}$ \\
\hline
\end{tabular}

\subsection{Teaching evaluation}

Teaching evaluation includes process evaluation and final evaluation.The process evaluation accounts for $70 \%$ of the total evaluation, and the final evaluation accounts for $30 \%$.Process evaluation includes $20 \%$ of online learning, $30 \%$ of classroom tasks and $20 \%$ of homework. The final evaluation provides the basis for the offline assessment tasks and the final results.

\section{EFFECT ANALYSIS}

Through the application of online and offline blending teaching mode to the 2018 and 2019 students in the course of management modeling and solution, questionnaire survey is conducted in each implementation stage during the teaching and training process. The content of the questionnaire includes the satisfaction of online and offline blending teaching, the difficulty of completion, teaching effect, etc.Combined with the questionnaire and platform data feedback, the overall situation is as follows:

\subsection{Results feedback before class}

After the pre class task is arranged, the platform data shows that the completion degree of pre-class task is $100 \%$. The contents of the questionnaire are as follows: 1 . The difficulty of the students to complete (Figure 3 ); 2 . The time taken by the students before class (Figure 4);

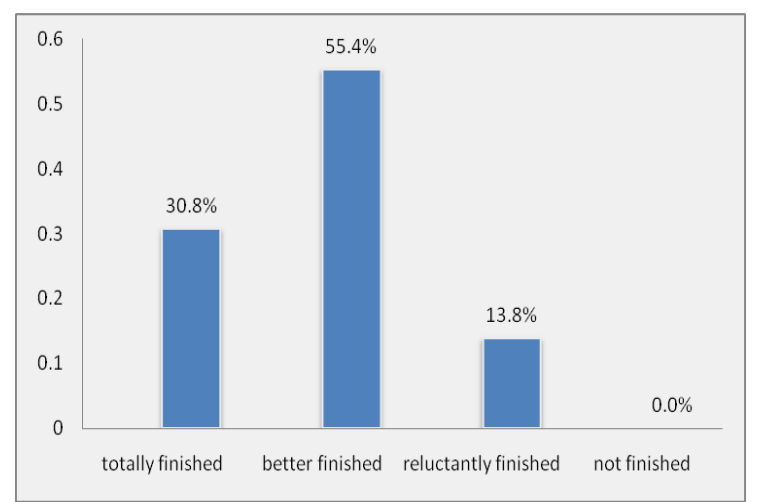

Figure 3 Survey of students completion

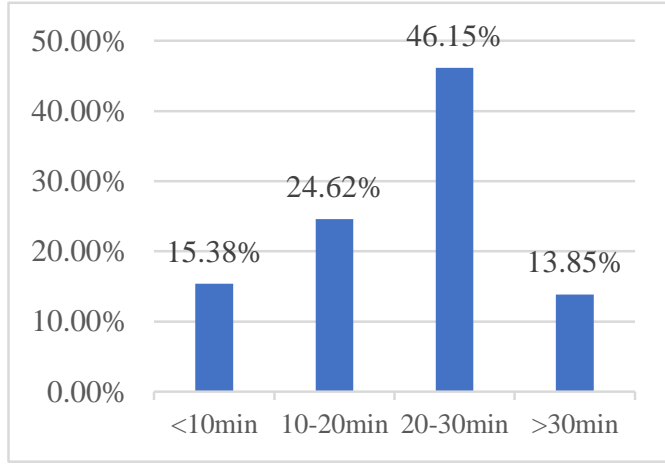

Figure 4 Online learning time occupation

From the results of the questionnaire, $86.2 \%$ of the students can complete the pre-class learning better, and $13.8 \%$ of the students feel that it is difficult to complete the pre-class learning.Most students adapt to the online learning task before class. The completion time is within 30 minutes, which is in line with the actual needs and will not cause any burden to the students.

\subsection{Student satisfaction}

After learning the course, in order to understand the online and offline teaching satisfaction.Is it recommended to use online and offline Blending Teaching in this course.The results show that $69.23 \%$ of the students are highly recommended, and $29.23 \%$ of the students are more recommended to use blending teaching (Figure 5).Most of the reasons recommended in the follow-up questionnaire are high flexibility, strong pertinence and high teaching efficiency.

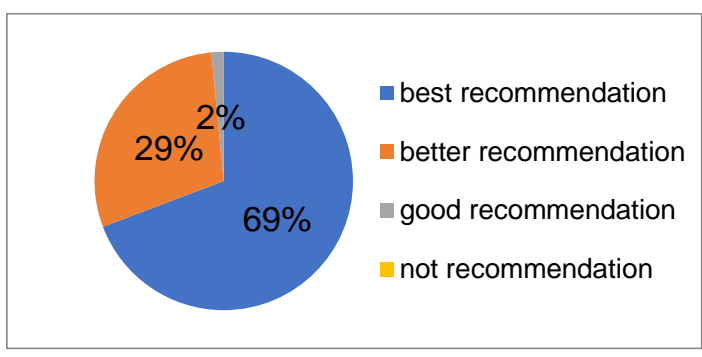

Figure 5 Student satisfaction survey 


\subsection{Analysis of teaching effect}

After using the online and offline blending teaching mode reform, compared with the traditional offline teaching mode, the average score of students has improved.At the same time, in the follow-up courses and students\&apos; graduation design and other modeling aspects, the practical ability has been improved.In particular, online teaching videos can be watched repeatedly, and students can check the knowledge at any time.At the same time, the flexibility of online course learning time and the accurate grasp of knowledge doubts improve the teaching efficiency.

\section{CONCLUSION}

Through the practice of teaching reform, the online and offline blended teaching mode makes full use of the advantages of online teaching and offline teaching, and uses the wide resources of Internet plus to serve teaching. It has been widely praised by both sides of the teaching.

\section{REFERENCES}

[1] Wang Pengjiao. Research on the Application of Flipped Classroom Teaching Design Mode Based on SPOC in Open University $[\mathrm{J}]$. China Audio Visual Education, 2013, (12): 79-86

[2] Xu Longzhi, Qian Huasheng. Research on the Mixed Higher Vocational Education Mode Based on the Pan Ya SPOC Platform -- Taking the Course of "International Trade Practice" as an Example [J]. Hebei Vocational Education, 2017, (10): 10-13

[3] Qin Jinruo. Research on the Construction of SPOC Teaching Design Mode Based on Five-star Teaching Principle [J]. China Distance Education, 2017, (6): 33-29

[4] Wu Di. Research on the Application of SPOC Based Blending Learning Mode [D]. Chongqing: Chongqing Normal University, 2017: 40-44

[5] Zhong Wenji, Zhang Zhonghai. Research on mixed teaching mode and its effect based on SPOC [J]. China Vocational and technical education, 2018 (20): 38-41 